\title{
VEGETAL COMMUNITIES FROM ICE-FREE AREAS OF COPACABANA, KING GEORGE ISLAND, ANTARCTICA
}

http://dx.doi.org/10.4322/apa.2014.004

Antonio Batista Pereira" ${ }^{1,2 *}$, Márcio Rocha Francelino ${ }^{2,3}$ \& Luiz Fernando Wurdig Roesch ${ }^{1,2}$

Universidade Federal do Pampa - UNIPAMPA, Rio Grande do Sul, Brasil

${ }^{2}$ Instituto Nacional de Ciência e Tecnologia Antártico de Pesquisas Ambientais - INCT-APA

${ }^{3}$ Universidade Federal Rural do Rio de Janeiro - UFRRJ, Rio de Janeiro, Brasil

*e-mail: antoniopereira@unipampa.edu.br

The vegetal communities from ice-free areas of King George Island show a close relationship with many environmental factors. In this respect, the Antarctic vegetal communities have become a good indicator for the study of climate change, geomorphology and hydrology. Measuring the actual area occupied by each type of community will help to monitor the development of the community and better understand the geo-environmental structure of ice-free areas in Antarctic (Figure 1).

The aim of this study has been to map and evaluate the ecological relationships of the vegetal communities with ice-free areas adjacent to Admiralty Bay - Antarctica.

The study was carried out in about 450 hectares of ice-free areas located on the west coast of Admiralty Bay, King George Island, Antarctica. The whole area was mapped using a differential GPS (DGPS) model Promark 2. The DGPS was run in the cinematic mode and the coordinators were corrected through the use of a base station and the Ashtech Solutions ${ }^{\circledR} 2.6$ programme. The technique allows for a $50 \mathrm{~cm}$ precision. The vegetal communities were delimitated by using the square method adapted to the Antarctic conditions and based on its floristic composition, physiognomy and association.

Seven vegetal communities were identified by this methodology:

1. Deschampsia Communities; are located in areas found in rocky elevations were the predominant vegetation is composed of Deschampsia antarctica Desv. (Poaceae) (Figure 2), associated with Colobanthus quitensis (Kunth.) Bart. (Caryophylaceae), and mosses represented by small populations of Sanionia uncinata Hedw. Loeske in dry areas and Bryum spp. in wet areas.

2. Deschampsia and moss communities; these communities occur far from the coastal zone. The presence of Deschapsia antarctica decreases considerably in size and density but there is an increase in the presence of Colobathus quitensis and mosses mainly Sanionia uncinata and Polytrichastrum alpinum (Hedw.) G.L.Sm. in the places under influence of birds. In others areas the predominant populations found, were Polytrichum juniperinum Hedw, P. strictum Brid. and P. piliferum Hedw.

3. Mosses and Deschampsia communities; these are very similar to the Deschampsia and moss communities. However, the major difference is related to the greater biodiversity and biomass of mosses in association with flowering plants. The presence of these communities is strongly associated with the soil moisture and drainage lines.

4. Carpets of moss communities; in these communities there is a predominance of Sanionia uncoinata many in those areas with absence of soil. In this case, the $S$. uncinata grows directly on the surface of the rocks.

5. Moss communities; the occurrence of these communities is associated with the presence of soil. When soil is present, the biodiversity of mosses is relatively large with the predominance of Polytrichum spp, Syntrichia spp and many species of Bryum. 
